\title{
6.15 Модель додаткової професійної підготовки майбутніх фахівців туристичного супроводу до реалізації програм культурно-пізнавального туризму
}

Туризм сьогодні розвивається шаленими темпами не тільки у світі, але й і в нашій державі також. Це супроводжується виділенням нових видів туризму в окремі туристські напрямки та розвитком вже чинних видів, що, в свою чергу, вимагає поповнення туристської сфери професійно підготовленими туристськими кадрами.

Одним 3 найдинамічніших секторів туризму $є$ культурно-пізнавальний туризм, який відчуває в даний час дефіцит у професійно підготовлених, конкурентоспроможних на вітчизняному ринку праці фахівцях.

Під культурно-пізнавальним туризмом у нашому дослідженні розуміються туристські відвідування пам’яток історії та культури, туристських територій та об’єктів культурної спадщини [Любіцева, 2008].

Аналіз програм підготовки студентів у професійних закладах освіти різного ступеню акредитації туристичного профілю свідчить про недостатню представленість питань, пов'язаних 3 професійною підготовкою студентів до реалізації програм культурно-пізнавального туризму. У зв'язку з цим було виявлено об’єктивно наявне протиріччя: між, 3 одного боку, потребою туристського ринку в професійно-підготовлених фахівцях, які здійснюють діяльність з реалізації програм культурно-пізнавального туризму, а 3 іншого недостатньою представленістю в теорії та методиці професійної освіти питань, пов’язаних з підготовкою фахівців з культурно-пізнавального туризму.

Резюмуючи результати проведеної нами оцінки готовності студентів туристського закладу освіти до реалізації програм культурно-пізнавального туризму, необхідно відзначити наступне:

- оцінка готовності студентів проводилася за трьома критеріями: психологічним, діяльнісним і мотиваційним; 
- загальна готовність студентів, виходячи 3 сукупності показників, отриманих в ході діагностики, оцінюється як недостатня та вимагає відповідного педагогічного забезпечення;

- реалізація програм культурно-пізнавального туризму в умовах туристського навчального закладу вимагає додаткової професійної підготовки студентів.

3 огляду на сукупність даних, отриманих в ході діагностичного етапу нашого дослідження, ми приходимо до наступного висновку: готовність студентів до реалізації програм культурно-пізнавального туризму не відповідає необхідному професійному рівню. Враховуючи це, нами була розроблена модель додаткової професійної підготовки, яка покликана забезпечити необхідний психологічний і практичний рівень готовності майбутніх фахівців туристичного супроводу до реалізації програм культурно-пізнавального туризму.

Модель додаткової професійної підготовки студентів до реалізації програм культурно-пізнавального туризму формується з урахуванням базових принципів освіти в туризмі [Федорченко, 2004]:

- демократизація - відкритість туристської освіти, залучення до неї уваги туристських підприємств та установ в освітній системі відносин рівноправності, співробітництва, децентралізації управління, варіативність змісту, форм i методів навчання;

- гуманізація - орієнтація всіх складових навчально-виховного процесу на особистість слухача, повагу його професійної гідності, подолання відчуження слухачів та викладацького складу від освітнього процесу, відхід від звички озиратися на усередненого студента, створення умов для розвитку соціальної активності молодого фахівця, розкриття його творчих можливостей;

- гуманітаризація - надання значущості туристським наукам про єдність туристського світу, взаємозв’ язку суспільства та людини, що дозволяє збагатити ii духовний світ, сформувати життєву позицію й утвердитися в якості професіонала-фахівця; 
- фундаменталізація - впровадження в навчальний процес теорій високого ступеня узагальнення, які мають підвищену інформаційну місткість і універсальну застосовність;

- безперервність - єдиний процес, що охоплює всі ступені та рівні освіти, що обумовлює формування у студентів і слухачів навичок самоосвіти та вміння орієнтуватися в дедалі більшому потоці туристської інформації;

- індивідуалізація - облік всієї системи індивідуальних і колективних форм роботи 3 обдарованими студентами, а також введення індивідуальних навчальних планів, різних видів навчання з різним обсягом підготовки.

Модель додаткової професійної підготовки студентів до реалізації програм культурно-пізнавального туризму реалізує наступну мету - розширити знання студентів про культурно-історичну спадщину та сформувати у них вміння представляти об'єкти культурно-історичної спадщини в якості об'єктів культурно-пізнавального туризму.

Основою змісту навчальної діяльності додаткової професійної підготовки студентів до реалізації програм культурно-пізнавального туризму служить вивчення компонента «Культурно-пізнавальний туризм», що складається 34 модулів: «Пам'ятники та ансамблі», «Твори ландшафтної архітектури», «Визначні місця» та «Основи екскурсійної справи».

Обсяг знань і умінь, отриманих студентами в рамках професійної освіти, дає можливість здійснювати ефективну професійну діяльність в області розробки туристичних продуктів, їх реалізації та супроводу, але не $є$ достатнім для успішної професійної діяльності, тому що не передає студенту всієї повноти специфічних знань в цій області.

Відповідно до визначень модулів навчальної діяльності студентів i критеріями їх класифікації, будується зміст додаткової професійної підготовки.

У процесі додаткової професійної підготовки студентами освоюється 4 етапи:

I етап - теоретичний: освоєння теоретичних знань про об’єкти культурноісторичної спадщини (пам’ятники, ансамблі, твори ландшафтної архітектури, 
визначні місця). Даний етап є початковим (вступним); він характеризується первинним теоретичним ознайомленням студентів 3 об’єктами культурної спадщини через вивчення їх історії виникнення та розвитку (генезис), ознайомлення 3 загальними основами культурології, державними та міжнародними принципами охорони об’єктів культурно-історичної спадщини, українським і міжнародним законодавством, що регулює питання, пов’язані 3 категоруванням об’єктів культурно-історичної спадщини, їх охорони і таке інше.

II етап - ознайомлювальний: безпосереднє ознайомлення 3 об’єктами культурно-історичної спадщини (заняття у формі навчальних екскурсій та виїзних семінарів на об’єкти культурно-історичної спадщини). Даний етап супроводжується такою формою навчальної діяльності, як навчальні екскурсії на об’єкти культурно-історичної спадщини; студенти знайомляться 3 об'єктами культурно-пізнавального туризму та теоретично осмислюють їх при безпосередньому контакті на базі отриманих на першому етапі знань.

III етап - професійно-орієнтований: освоєння теоретичних знань про об’єкти культурно-історичної спадщини як об’єкти культурно-пізнавального туризму; вивчається зв’язок туризму 3 культурою; об'єкти культурнопізнавального туризму розглядаються вже не тільки з позиції їх культурологічної цінності, але також і 3 позиції дослідження цього об’єкта культурнопізнавальним туризмом як туристичного ресурсу.

IV етап - виробничий: виробнича практика в туристичних фірмах та екскурсійних бюро. Передбачає безпосередню участь студентів у розробці та проведенні екскурсій; спрямований на вироблення практичних умінь щодо реалізації програм культурно-пізнавального туризму. Необхідною теоретичною базою виступають знання, отримані студентами в ході перших трьох етапів.

Модель додаткової професійної підготовки студентів до реалізації програм культурно-пізнавального туризму передбачає супровід навчання такими формами навчальної діяльності, як: лекції, відеолекції, конференції, семінари, дискусії, круглі столи, навчальні та виробничі практики, навчальні екскурсії. Передбачається організація спецсемінарів 3 представниками туристичних 
організацій та екскурсійних бюро, що займаються організацією культурнопізнавальних турів з обговоренням проблем галузі.

Модель додаткової професійної підготовки студентів до реалізації програм культурно-пізнавального туризму охоплює базові принципи, такі як [Любчук, 2018]:

- гуманізація - принцип, який констатує пріоритет людських цінностей над виробничими, економічними, адміністративними;

- культуро-орієнтованість - принцип розгляду об'єктів культурноісторичної спадщини з позицій їх генезису та значення для сучасної культури;

- історизм - принцип розгляду об’єктів культурно-історичної спадщини, природних і соціально-культурних явищ в динаміці їх зміни, становлення в часі, у закономірний історичний розвиток, що передбачає аналіз об'єктів дослідження у зв'язку з конкретно-історичними умовами їх існування;

- ціннісна орієнтація - свій відбиток у свідомості людини цінностей, визнаних нею як стратегічних життєвих цілей i загальних світоглядних орієнтирів, без яких вона не мислить свого життя;

- наочність - практично реалізоване уявлення (безпосереднє або опосередковане) об'єктів культурно-пізнавального туризму студентом.

Модель додаткової професійної підготовки студентів до реалізації програм культурно-пізнавального туризму включає методи навчання - наочні, словесні, практичні, і засоби - наука, мораль, матеріальні цінності, персоналії, мистецтво.

Справжня модель відповідає вимогам компетентності фахівця туристичного супроводу у сфері культурно-пізнавального туризму.

Компетенції в самому узагальненому їх розумінні - це очікувані та вимірювані конкретні досягнення випускників, які визначають, що буде здатний робити випускник по завершенню освітньої програми [Галасюк, 2019].

Для апробації моделі додаткової професійної підготовки студентів до реалізації програм культурно-пізнавального туризму, нами був проведений формувальний експеримент. 
Зі студентами, майбутніми фахівцями сфери туризму, був проведений ряд теоретичних, практичних і мотиваційних занять, представлених як додаткова професійна підготовка фахівців до реалізації програм культурно-пізнавального туризму. В ході підготовки зі студентами були проведені наступні заняття:

1. Теоретичні, що охоплювали передачу знань 3 дисциплін спрямованих на вивчення різноманітних туристичних об'єктів, та включали дисциплінарні модулі: «Пам’ятники та Ансамблі», «Твори ландшафтної архітектури» та «Визначні місця». Зі студентами було вивчено різні класифікації об’єктів культурно-історичної спадщини, передано термінологічну базу в області культурно-пізнавального туризму, висвітлені питання потенціалу та перспектив розвитку культурно-пізнавального туризму в нашій державі та за іiі межами, вивчена діяльність організацій, що здійснюють діяльність в області культурнопізнавального туризму, нормативно-правова основа цієї діяльності, досвід підготовки фахівців в області культурно-пізнавального туризму інших країн. Об'єкти культурно-історичної спадщини вивчались студентами безпосередньо (в рамках навчальних екскурсій) і опосередковано - через літературні та аудіовізуальні джерела інформації. Формувалося ставлення студентів до культури як базової цінності людства, до гуманності та толерантності як до принципів взаємодії між людьми.

2. Практичні, представлені як підготовка рефератів, доповідей і повідомлень 3 проблематики культурно-пізнавального туризму, перспективи його розвитку, законодавчо-правового забезпечення в культурно-пізнавальному туризмі, бізнес-планування культурно-пізнавального туру (екскурсіі), практика в туристичних фірмах та екскурсійних бюро. Дані заняття забезпечувалися великим обсягом матеріалів, пов'язаних з історією, культурою, етнографією, екологією туризму; джерелами 3 проблематики культурно-пізнавального туризму, нормативними документами в галузі культурно-історичної спадщини, a також 3 документами ЮНЕСКО, концепціями розвитку культурнопізнавального туризму, матеріалами різних конференцій 3 проблематики культурно-пізнавального туризму. Таким чином, студенти отримали широкий 
теоретичний інструментарій для виконання робіт по культурно-пізнавальному туризму.

3. Мотиваційні, що включали проведення вільних дискусій зі студентами, дискусій на задані теми, обмін думок (в формах «студент-студент», «студентвикладач») і співбесіду. Більше уваги в рамках мотиваційних занять віддавалося особистісній активності студентів в процесі зміни відносин до навчальної діяльності та предмету вивчення. Встановлювалася динаміка зміни ставлення слухачів до пізнавальної діяльності, активного освоєння змісту освіти, зміни їх саморефлексії та мотивації. В ході підготовки студентами було продемонстровано інтенсивне опанування одержуваними знаннями.

Практичний блок містив підготовку доповідей, повідомлень i тез 3 проблематики культурно-пізнавального туризму. Підготовка матеріалів здійснювалася студентами на базі отриманих знань в області культурнопізнавального туризму. До матеріалів було пред’явлено наступні вимоги:

1. Робота повинна бути самостійно виконаним, закінченим науковим дослідженням. Робота може бути виконана як українською, так і іноземною мовою.

2. Робота може бути виконана як одним автором, так і авторським колективом студентів (не більше трьох авторів).

3. Відомості, представлені в роботі, повинні бути перевіреними та вірогідними.

4. Обсяг роботи повинен бути не менше 10 і не більше 40 друкованих сторінок.

5. Зміст роботи має бути пов'язаним з їі тематикою.

Тематичний перелік пропонованих до виконання робіт було максимально розширено з метою виявлення інтересу студентів до тієї чи іншої проблематики в області культурно-пізнавального туризму.

Мотиваційний блок підготовки охоплював проведення вільних дискусій зі студентами в режимі обміну думок з питань культурно-пізнавального туризму та культури в цілому, а також персональної співбесіди. Цей блок реалізував 
наступні завдання: виявлення мотивування студентів, що готуються до реалізації програм культурно-пізнавального туризму; визначення мотивів студентів, що реалізують програми культурно-пізнавального туризму; виявлення цільової аудиторії студентів, здатних реалізувати програми культурно-пізнавального туризму.

Процес проведення формувального експерименту можна відзначити такими особливостями: динамічністю й інтенсивністю додаткової підготовки; високим ступенем залученості в навчальний процес; високою часткою творчої роботи студентів в ході формувального експерименту; опануванню конкретними знаннями в питаннях культурно-пізнавального туризму та світової культури; опанування конкретними навичками наукової роботи (суспільно-колективна робота, індивідуальна робота, робота зі спеціальною літературою).

Отже, ефективність побудованої моделі доводять результати формуючого експерименту, що демонструє досягнення поставленої мети. Була отримана комплексна оцінка готовності студентів до реалізації програм культурнопізнавального туризму, виходячи з трьох базових критеріїв: знаннєвого (оцінка теоретичних знань студентів про об’єкти культурно-історичної спадщини); діяльнісного (практично напрацьовані вміння та навички студентів, необхідні для реалізації програм культурно-пізнавального туризму); мотиваційного (визначення особистісної потреби студента в додатковій професійній підготовці до реалізації програм культурно-пізнавального туризму). Показники кожного 3 критеріїв в експериментальній групі зросли щодо показників контрольної групи.

Студенти опанували знання в області культурно-пізнавального туризму, об’єктів культурно-історичної спадщини, культурології; змісті культурнопізнавального туризму, його роль у системі світового туризму; термінологічної бази в області культурно-пізнавального туризму. Студенти продемонстрували готовність професійного використання знань не тільки в науковій, але і в практичній роботі.

Студентами були отримані необхідні вміння та навички для реалізації програм культурно-пізнавального туризму, такі як: вміння працювати 3 
науковою літературою, оволодіння спеціальним лексичним апаратом англійської мови 3 культурно-пізнавального туризму та об'єктів культурно-історичної спадщини в цілому, навички комунікацій - вміння ясно, послідовно і професійно висловлюватися 3 питань культурно-пізнавального туризму. Опанування комунікативними навичками дозволяє студентам професійно реалізувати завдання взаємодії фахівця туристичного супроводу та туриста, вибудовувати комунікації всередині туристських груп, а також забезпечує можливість побудови комунікацій серед представників різних культурних груп. Зросла мотивація студентів до реалізації програм культурно-пізнавального туризму. 